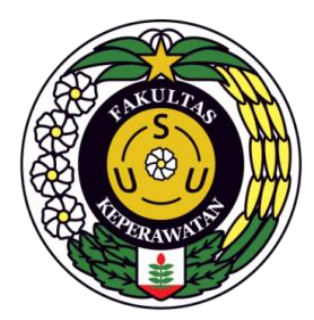

KAJIAN ILMIAH

TANTANGAN PERAWAT MANAGER DALAM PEMBERIAN $R E W A R D$ UNTUK MENINGKATKAN KEPUASAN KERJA PERAWAT

DISUSUNOLEH :

RINI DEBORA SILALAHI (197046015)

rinisilalahi19@gmail.com

PROGRAM STUDI MAGISTER KEPERAWATAN

FAKULTAS KEPERAWATAN

UNIVERSITAS SUMATERA UTARA

2019 


\title{
TANTANGAN PERAWAT MANAGER DALAM PEMBERIAAN REWARD UNTUK MENINGKATKAN KEPUASAN KERJA PERAWAT
}

\author{
Rini Debora Silalahi \\ Mahasiswa Program Studi Magister Keperawatan Fakultas Keperawatan Universitas \\ Sumatera Utara
}

\begin{abstract}
ABSTRAK
Kinerja perawat adalah aktivitas perawat dalam mengimplementasikan suatu wewenang, tugas dan tanggung jawabnya dengan sebaik-baiknya. Dari hasil survey didapatkan hasil analisis sementara rendahnya kinerja perawat pada kepuasan kerja, sistem penghargaan, motivasi kerja perawat tersebut. Tujuan kajian untuk melihat pengaruh reward terhadap kepuasan kerja serta motivasi perawat. Dari beberapa penelitian diperoleh hasil terdapat pengaruh signifikan antara pemberian reward dengan kepuasan kerja perawat. Kesimpulan. Perlu ada perhatian lebih kepada perawat dalam menciptakan kepuasan kerja dengan mensesuaikan pekerjaan sesuai dengan kemampuannya, peningkatan gaji sesuai dengan pendidikan dan masa kerjanya, serta menciptakan suasana kerja yang kondusif.
\end{abstract}

\section{Kata Kunci : Perawat manager, Reward, Kepuasan kerja}

\section{A. Latar Belakang}

Pelayanan keperawatan yang diberikan oleh seorang perawat sangat mempengaruhi mutu asuhan keperawatan yang akan diterima oleh pasien dalam rangka mencapai tingkat kesehatan yang optimal. Tingkat kesehatan yang optimal ini dapat dicapai jika motivasi kerja perawat tinggi. Padahal, kondisi kerja perawat Indonesia saat ini masih belum memuaskan, hal ini dapat dilihat dari rendahnya system reward rumah sakit negeri daripada rumah sakit swasta, yang secara otomatis mempengaruhi mutu pelayanan rumah sakit Kondisi yang terjadi di Indonesia masih banyak yang mengeluhkan adanya pelayanan keperawatan yang kurang optimal. Banyak pasien yang mengeluhkan perawat kurang ramah dan perawat lambat dalam menangani keluhan pasien. Keperawatan menjadi salah satu profesi dibidang kesehatan yang mempunyai kontribusi terhadap kualitas pelayanan (Haryati, 2014; Vera, 2016). Rendahnya imbalan jasa bagi perawat selama ini juga mempengaruhi kinerja perawat (www.kompas.com). 
Kinerja perawat sebenarnya sama dengan prestasi kerja diperusahaan. Perawat ingin diukur kinerjanya berdasarkan standar obyektif yang terbuka dan dapat dikomunikasikan. Jika perawat diperhatikan dan dihargai sampai penghargaan superior, mereka akan lebih terpacu untuk mencapai prestasi pada tingkat lebih tinggi (Faizin \& Winarsih, 2008; Bawono, \& Nugraheni, 2015).

Kinerja perawat akan dipengaruhi oleh Faktor individu, Faktor psikologis (persepsi, peran, sikap, kepribadian, motivasi, dan kepuasan kerja), dan faktor organisasi (struktur organisasi, desain pekerjaan, kepemimpinan, sistem penghargaan (reward system) (Wirakristama \& suharnomo, 2011; Nursalam, 2016).

Reward yang diterima oleh perawat pelaksana selama ini dari RS adalah gaji pokok, tunjangan fungsional, insentif/ jasa pelayanan, dan pengembangan karir. Gaji pokok dan tunjangan fungsional sudah ditentukan dari Pemda melalui APBD. Insentif/jasa pelayanan berasal dari penerimaan rumah sakit, yang didapatkan dari banyaknya pasien yang di rawat. Perawat juga menyatakan bahwa karir mereka tidak berkembang, sebab tidak ada program pengembangan karir dari rumah sakit sendiri. Pengembangan karir disini berupa peningkatan pendidikan, pelatihan - pelatihan, seminar, lokakarya, dan lain sebagainya. Perawat yang ingin melanjutkan pendidikan yang lebih tinggi tidak mendapatkan bantuan dari rumah sakit dan harus dengan biaya sendiri dan untuk pengajuan ijin belajar prosesnya lama. Oleh karena itu kodisi diatas menjadi tantangan pada manager perawat dalam pemberian reward untuk meningkatkan layanan keperawatan.

\section{B. Tujuan}

Tujuan kajian ini adalah untuk melihat bagaimana peran manager perawat dalam pemberian reward pada perawat guna meningkatkan layanan keperawatan pada pasien.

\section{Metode}

Kajian ini dilakukan dengan mencari sumber data baik dari jurnal maupun bukubuku yang berhubungan dengan kepemimpinan yang efektif kepala ruangan dalam menciptakan budaya keselamatan pasien di rumah sakit. Artikel penelitian yang digunakan bersumber dari Repository USU, Google Scholar. Penelusuran dilakukan dengan kata kunci sesuai dengan topik yaitu manajer perawat, reward, mutu layanan. 


\section{Hasil}

Berdasarkan penelitian Isnainy (2018) terhadap perawat pelaksana di ruang rawat inap Rumah Sakit Pertamina Bintang Amin Bandar Lampung diketahui nilai koefisien jalur pengaruh Reward terhadap kinerja perawat diperoleh sebesar 0,105 dengan nilai probabilitas $0,048<$ nilai signifikansi 0,05 , artinya terdapat pengaruh yang signifikan reward terhadap kinerja perawat. Berdasarkan hasil penelitian didapatkan bahwa reward yang baik akan meningkatkan kinerja perawat.

\section{E. Pembahasan}

Berdasarkan hasil penelitian yang dilakukan oleh peneliti terhadap perawat pelaksana di ruang rawat inap Rumah Sakit Pertamina Bintang Amin Bandar Lampung diketahui nilai koefisien jalur pengaruh Reward terhadap kinerja perawat diperoleh sebesar 0,105 dengan nilai probabilitas $0,048<$ nilai signifikansi 0,05 , artinya terdapat pengaruh yang signifikan rewardterhadap kinerja perawat. Berdasarkan hasil penelitian didapatkan bahwa rewardyang baik akan meningkatkan kinerja perawat.

Menurut Gibson (1997) dalam Nursalam (2016), faktor yang berpengaruh terhadap kinerja adalah faktor organisasi. Dalam faktor organisasi terdapat reward yang mempunyai peranan penting dalam menciptakan kinerja yang baik. Hasil penelitian ini sesuai dengan teori yang dikemukan oleh Notoadmodjo (2012), Kinerja seorang tenaga kerja atau karyawan dalam suatu organisasi atau institusi kerja dipengaruhi oleh banyak faktor, baik faktor dari dalam karyawan itu sendiri maupun faktor lingkungan atau organisasi kerja itu sendiri. Jika perawat diperhatikan dan dihargai sampai penghargaan superior, mereka akan lebih terpacu untuk mencapai prestasi pada tingkat lebih tinggi.

Hasil penelitian ini sejalan dengan penelitian yang dilakukan Febrianti. (2014) dengan judul Pengaruh reward dan punishment terhadap motivasi kerja serta dampaknya terhadap kinerja didapatkan bahwa reward mempunyai pengaruh yang signifikan terhadap kinerjadengan nilai pengaruh sebesar 0,227 dengan taraf signifikan 0,042. Dampak motivasional dari tujuan kinerja dan reward plan telah dikenal lama. Antara lain dikemukakan Frederick Taylor yang secara ilmiah menciptakan berapa banyak pekerjaan 
dengan kualitas tertentu seorang individu harus ditugaskan setiap hari. Ia mengusulkan bahwa bonus didasarkan pada penyelesaian standar output. Kemudian goal setting berkembang menjadi management by objectives, suatu sistem manajemen yang menghubungkan partisipasi dalam pengambilan keputusan, penetapan tujuan, dan umpan balik (Wibowo, 2016).

Berdasarkan hasil penelitian pengaruh langsung reward terhadap kinerja perawat dapat terjadi pada perawat yang merasa mendapatkan rewardyang baik, sehingga dapat secara langsung terbentuk kinerja yang baik. Pada kondisi ini perawat belum membutuhkan motivasi dalam menilai rewarduntuk mencapai kinerja yang baik. Pengaruh tidak langsung pertama, pengaruh rewardterhadap kinerja perawat melalui motivasi perawat. Berdasarkan hasil penelitian semakin baik reward perawat yang didapat maka semakin baik kinerja perawat dalam pekerjaannya. Reward mempengaruhi perawat dalam bertindak terhadap pelayanan sehingga tercipta kinerja yang baik. Kinerja akan baik apabila didukung dengan reward yang baik. Dengan rewardyang baik tetapi jika motivasi perawat kurang maka akan menurunkan kinerja perawat tersebut. Oleh karena itu, kinerja selain didukung dengan rewardyang baik harus diikuti juga dengan motivasi yang baik. Mengingat pentingnya kinerja perawat, maka ada beberapa hal yang harus diperhatikan oleh pihak manajemen rumah sakit agar perawat tidak resign dari rumah sakit. Terutama masalah insentif yang harus jelas untuk perawat, dan harus diberikan setiap bulannya.

Hasil penelitian ini sesuai dengan teori yang dikemukan oleh Gibson (1997) dalam Nursalam (2016), ada 3 faktor yang berpengaruh terhadap kinerja adalah faktor psikologis: persepsi, peran, sikap, kepribadian, motivasi, dan kepuasan kerja. Penelitian ini sejalan dengan penelitian yang dilakukan oleh Johan (2014) dengan judul Pengaruh motivasi terhadap kinerja karyawan di Restoran Soho Makassar didapatkan hasil penelitian motivasi memiliki hubungan yang kuat dan positif serta signifikan terhadap kinerja karyawan dengan nilai pengaruh sebesar 0,501

Pengaruh tidak langsung yang kedua yaitu kepuasan kerjaterhadap kinerja perawat melalui kepuasan kerja perawat. Selain reward ternyata kepuasan kerjamemiliki peranan 
penting terhadap kinerja. Perawat yang mendapakan kepuasan kerja cenderung memiliki kinerja yang baik karena kepuasan kerjadiperlukan bagi perawat untuk meningkatkan kemandirian perawat dalam bertindak dan mengambil keputusan dalam pelayanan keperawatan. Pengukuran kepuasan kerja dimaksudkan agar rumah sakit dapat mengetahui apa yang menjadi kebutuhan, keinginan dan harapan dari perawat. Perawat adalah aset

rumah sakit yang paling berharga. Apabila perawat puas, mereka akan menghasilkan kinerja yang sesuai dengan harapan rumah sakit. Melalui pengukuran kepuasan kerja, diharapkan rumah sakit akan mampu menentukan prioritas untuk menciptakan kepuasan kerja (Hasibuan, 2009; Rangkuti, 2013).

\section{F. Penutup}

Perlu ada perhatian lebih kepada perawat dalam menciptakan kepuasan kerja dengan mensesuaikan pekerjaan sesuai dengan kemampuannya, peningkatan gaji sesuai dengan pendidikan dan masa kerjanya, serta menciptakan suasana kerja yang kondusif. 


\section{Daftar Pustaka}

Anne, Ahira. 2012. Konsep dan Implementasi Analisis Kebijakan Kesehatan . Diakses dari http://www.AnneAhira.com/artikel.

Departemen Kesehatan RI. 2009. Sistem Kesehatan Nasional. Jakarta :Departemen Kesehatan RI

Gupta M, Mavalangkar D. \& Poonam Trivandi. A Study of Referral System for EmOC in Gujarat. Indian Institute of Management. WP J, 2009;6(2):2-50.

Herlambang Sulung, 2013, Kesiapan Indonesia Dalam Menghadapi MEA 2015 Melalui Kebijakan Redenominasi, Purwokerto: FE Universitas Jenderal Soedirman.

Kementerian Kesehatan, Tantangan Pembangunan Kesehatan Diakses dari http://www.depkes.go.id.

McEachen, Irene dan Koegh, Jim. (2018). Manajemen Keperawatan Demystified. Yogyakarta: Penerbit Andi.

Notoadmojo. (2012). Metode Penelitian Kesehatan. Jakarta: Rineka Cipta.

Peraturan Menteri Kesehatan Republik Indonesia No 46 Thaun 2013 tentang Registrasi Tenaga Kesehatan Melalui www.depkes.go.id diakses tanggal 16 Juli 2012.

Simamora, R. H. (2013). Upaya Pembinaan Perawat Di Rumah Sakit Ngesti Waluyo Parakan Temanggung Jawa Tengah. Jurnal Keperawatan Soedirman,8(2).

Simamora, R. H. (2014). Buku Ajar Manajemen Keperawatan. Jakarta: Penerbit Buku Kedokteran EGC.

Simamora, R. H. (2019). Menjadi Perawat yang: CIH'HUY. Surakarta: Kekata Publisher.

Sumijatun. (2010). Konsep Dasar Menuju Keperawatan Profesional. Jakarta: Trans Info Media.

Surya Utama. 2012. Dasar-Dasar Analisis Kebijakan Kesehatan. Diakses dari http://repository.usu.ac.id

Weinhold I, \& Gurtner S. (2014). Understanding shortages of sufficient health care in rural areas. Health Policy (Amsterdam, Netherlands), 118(2), 201-14. 4. 
